\title{
CIRCADIAN OSCILLATORS IN EUKARYOTES
}

\author{
Ingunn W. Jolma ${ }^{\mathbf{1}}$, Ole Didrik Laerum ${ }^{2}$, Cathrine Lillo ${ }^{\mathbf{1}}$, and Peter Ruoff ${ }^{\mathbf{1}}$ \\ ${ }^{1}$ Centre of Organelle Research, Faculty of Science and Technology, University of Stavanger, \\ Stavanger, Norway and ${ }^{2}$ The Gade Institute, Department of Pathology, Haukeland University \\ Hospital, N-5021 Bergen, Norway.
}

\begin{abstract}
The biological clock, present in nearly all eukaryotes, has evolved such that organisms can adapt to our planet's rotation in order to anticipate the coming day or night as well as to anticipate unfavorable seasons. As all modern high-precision chronometers, the biological clock uses oscillation as a timekeeping element. In this review we describe briefly the discovery, historical development, and general properties of circadian oscillators. The issue of temperature compensation is discussed and our present understanding of the underlying genetic and biochemical mechanisms in circadian oscillators are described with special emphasis on Neurospora crassa, mammals and plants.
\end{abstract}

\author{
Keywords \\ Circadian oscillators, biological clock, temperature compensation, clock genes, transcription, \\ translation, feedback regulation, photoperiodicity
}

\section{Introduction}

Androsthenes from Thasus, a member of an expedition sent out by Alexander the Great, made first systematic observations on diurnal rhythms in plants. Although his original report is lost, fragments describe that during his journey he observed astonishing leaf rhythms in Tamarindus indica which suggested to him that these trees were sleeping during the night $[1,2]$. The first modern report that leaf rhythms are endogenously generated date back to de Mairan, an astronomer, who showed that leaf rhythms in Mimosa plants continued even in the absence of an external light/dark cycle [3]. De Mairan's studies were quickly followed-up, as for example by the physician Zinn on 'plant sleep' [4], or by Linnaeus' famous 'flower clock' described in his Philosophia Botanica [5]. In the beginning of the $19^{\text {th }}$ century the pharmacist Julien-Joseph Virey found that human mortality shows daily and seasonal variations. Virey also reported on the effect of drugs with respect to their administration times, and appears therefore to be the first person working in the field which now is called "chronopharmacology" [6].

However, the endogenous character of plant leaf movements was not universally accepted. Wilhelm Pfeffer, while trying to demonstrate that leaf movements in bean plants were caused by environmental influences, showed by well-designed experiments, that these 
oscillations indeed have an endogenous cause [7]. During the same period, similar findings were made by Szymanski [8] on animals.

In the 1930's Erwin Bünning suggested that intracellular time measurement leads to seasonal adaptations, such as flower induction, migration and hibernation, which is based on an oscillatory and genetically determined physiological clock with a period of approximately one day. While Bünnings's hypothesis first caused major opposition, it became generally accepted during the 1950's [9, 10]. His textbook "The Physiological Clock" [10] still makes an interesting introduction to the field.

Today, the name circadian indicates that under free-running conditions the period length of these physiological oscillators is circa one day (derived from lat. dies, day and circa about) after a suggestion by Franz Halberg. Additional defining properties of circadian oscillators are: (i) being endogenously generated; (ii) showing a free-running rhythm; (iii) can be phase-shifted by environmental perturbations, for example by light, temperature, chemicals; (iv) they show entrainment, i.e., circadian oscillators can track rhythmic environmental changes, and (v) show temperature compensation, meaning that the free-running period is (approximately) the same at different but constant temperatures.

Circadian rhythms are important for the daily and seasonal adaptation of practically all higher (eukaryotic) organisms, but are also found in light-sensing prokaryotes such as cyanobacteria [11]. However, adaptation of organisms to their environments does not only involve circadian oscillations, but also ultradian as well as infradian oscillators [10, 12-16].

In this review we give a brief description of eukaryotic circadian oscillators with special emphasis on the model organisms Neurospora crassa, Arabidopsis thaliana and the mammalian clock. Drosophila, while a major model system, is left out here due to space limitations.

\section{Genetics and Model Organisms}

In the beginning of the 1970's [17] the first successfully generated clock mutants were generated with the fruit fly Drosophila melanogaster [18] and the filamentous fungus Neurospora crassa [19], and rats were found to lose their circadian rhythms by hypothalamic or suprachiasmatic lesions [20, 21]. Remarkably, in 1990 Ralph et al. could restore circadian wheelrunning activities in Syrian hamsters that had their suprachiasmatic nucleus (SCN) removed, by transplanting back intact SCN tissue [22], indicating that the mammalian circadian clock is located in the SCN [23].

Early genetic and molecular biology studies on Drosophila [24] and Neurospora [25] indicated a common mechanism involving a transcriptional translational negative feedback loop (Fig. 1) [26-30], but newer findings suggest the presence of multiple loops and oscillators [3136].

\section{Circadian oscillators are based on feedback mechanisms}

The study of biological clocks had always a good share of theoretical studies and modeling approaches [37-39]. Kinetic models of transcriptional-translational negative feedback loops, some based on Goodwin's equations [40, 41], showed that many aspects of circadian oscillations including temperature compensation and phase resetting can be described [38, 42-59]. Early predictions using the Goodwin oscillator indicated $[42,60]$ that clock protein stability/turnover should determine the circadian period length, where short period mutants should have a clock protein which is more rapidly turned over compared with wild-type, while in long period mutants the clock protein should be more stable than in wild-type. Using Neurospora, 
it was demonstrated that phosphorylation of the clock protein FREQUENCY (FRQ) is important for its stability [61-64]. When certain phosphorylation sites in FRQ were blocked (for example replacing Ser 314 by an Ile) [62], FRQ stability increases and leads, as theoretically predicted $[42,60]$, to larger period lengths. In several follow-up papers by the Liu group [65-67], it was found that phosphorylated FRQ is turned over by the ubiquitin-proteasome pathway [68]. The study of FRQ-decay kinetics in Neurospora clock mutants confirmed the theoretically predicted period-stability relationship with an intimate link to temperature compensation [53, 64]. Thus, Neurospora's circadian period appears to be a fine-tuned process including phosporylation / dephospohorylation reactions of FRQ by several kinases and phosphatases, leading to a regulated turnover through the ubiquitin-proteasome pathway [27, 28, 69-72]. Similar observations have also been made for mammalian systems showing that the decreased period for the CK1 $\varepsilon$ tau mutation in mice and Syrian hamsters is related to an increased degradation in PER-protein [73, 74]. Certain posttranslational regulation elements of clock proteins appear to be conserved from Neurospora to mammals and involve the kinases CK1 and CK2 and the phosphatase PP2A [69].

Positive feedback loops (Fig. 1) have also been identified as part of circadian clock mechanism, as for example in Drosophila [35, 75-78]. Some models showed that the presence of interlocked positive and negative feedback loops may increase the stability and tuneability of the oscillator [79], while in other cases [80, 81] the presence of an additional positive feedback did not seem to affect the robustness of the oscillator. In case of the Drosophila oscillator, which at present includes two negative and one positive feedback loop, the positive loop is necessary to describe the influence of dosage of the per-gene and vri- on the period [75, 82-84].

There is a close similarity from a mechanistic/kinetic viewpoint between circadian rhythms and in vitro physicochemical oscillators [85-96], as both have positive and negative feedback loops [97]. Today, the mechanisms of many physicochemical oscillators have been determined, including systems that even can show temperature compensation $[93,98,99]$.

\section{The Issue of Temperature Compensation}

Temperature compensation (TC) is one of the defining clock properties of circadian rhythms. TC means that the circadian period is homeostatically regulated towards variations in temperature, i.e., the circadian period is constant at different (constant) temperatures. TC is only operative within a certain, for the organism important temperature range. For most of the circadian oscillators the precise mechanism how TC is achieved is still not known. A variety of suggestions how TC may be achieved have been considered during the years $[38,51]$.

In the 'balancing/opposing reaction approach', first suggested in 1957 [100], then later kinetically formulated for chemical oscillators [54], each temperature-induced change in a rate constant of a reaction step will in principle lead to an increase or decrease in the period length. For certain combinations of activation energies the positive and negative influences of the various rate constants on the period length cancel and the system will show TC within a given temperature range. To achieve TC the activation energies need to be fine-tuned in such a way that the sum of the product between the sensitivities and the activation energies becomes zero [51, $101,102]$. This approach allows one to describe TC of any systemic property which depends on the rate constants, such as for non-oscillatory steady-state fluxes or steady-state concentrations [50], and has been extended to describe $\mathrm{pH}$-compensation [103, 104]. Several experimental findings suggest (see below) that 'balancing' is at least one mechanism to achieve temperature compensation in circadian rhythms.

Hong et al. [105] recently argued that a balancing approach would not be sufficiently 
robust to account for the many mutations, which do not affect temperature compensation. They propose a switch-like mechanism for circadian rhythms that concentrates period sensitivity in just two parameters, by forcing the system to alternate between a stable steady state and a stable limit cycle. Indeed, there appears to be a close relationship between robust homeostasis and temperature compensation [106], but such a relationship for circadian oscillators is still poorly understood.

Despite TC, temperature has a significant influence on other circadian properties such as entrainment, phase shifting, or amplitude [55].

\section{The Neurospora Circadian Clock The FRQ-oscillator}

Neurospora crassa is a model organism [107] that has been extensively used in the study of circadian rhythms [27, 28, 69, 70, 108-111]. In 1959 Pittendrigh [112] found that Neurospora shows a circadian rhythm in its asexual production of spores (conidia). The use of the band (bd) mutation introduced later by Sargent and coworkers [28, 107] allowed monitoring of the freerunning temperature compensated conidiation rhythm in growth tubes (Fig. 2). A firefly luciferase-based reporter assay was first constructed by Morgan et al. [113], where the sequence of the luciferase gene was partly optimized to reflect the codon usage by $N$. crassa. Both lightinduced and circadian activities could be continuously monitored using this assay. A fully codonoptimized system was recently generated by Gooch et al. [114], which showed a dramatic increase in the light output of the luciferase-catalyzed reaction and which has also been applied to study the output dynamics under conditions of choline deficiency [115] (see also $F R Q$ independent oscillators below).

The basic mechanism behind the conidiation rhythm is due to a transcriptional translational negative feedback loop, where the FRQ-protein inhibits its own transcription (FRQ oscillator, Fig. 3). WHITE COLLAR-1 (WC-1) and WHITE COLLAR-2 (WC-2) are Zn-finger proteins acting as a heterodimeric transcription factor, the so-called White Collar Complex (WCC). The WCC plays central roles in a variety of different physiological processes, including (blue) light activation of genes [107, 116-124], with WC-1 as a flavin-binding blue light photoreceptor. The frq promoter contains two light responsive elements (LREs), where the distral element ("clock (C)-box") [125] appears necessary for rhythmicity in darkness. Each LRE contains two GATN sequence repeats, each probably capable of binding the Zn-finger domain from either WC-1 or WC-2. In darkness, circadian rhythms are observed in frq-mRNA, FRQprotein, as well as in WC-1 [126]. Hong et al. [127] showed by model calculations that the binding of WCC to the frq-promoter is of importance for maintaining temperature compensation. Alternative to a rapid degradation of the complex between FRQ and WCC, in order to close the negative feedback loop, there is evidence for a FRQ-mediated clearance of WC-1 out of the nucleus [128]. Recent experimental evidence suggests that FRQ is rapidly shuttled between the nucleus and the cytoplasma [129], which may be part of a FRQ-mediated mechanism to clear WC-1 out of the nucleus.

While WC-1 has been considered to be always bound to WC-2, which has been found to be in excess compared to WC- 1 and at constant concentrations [120, 130, 131], recent ChIP experiments indicate differential binding affinities of WC-1, WC-2 towards the LREs and a breakup of the WCC [132]. It was found that WC-1 is always bound to both LREs, while binding of WC-2 in darkness to the C-box is oscillatory (circadian) and highly correlated with the binding of the chromatin-remodeling enzyme CLOCKSWITCH (CSW-1) to the C-box [132]. 
Due to a temperature-regulated alternative splicing mechanism, the FRQ-protein is found in a long (1-FRQ) and a short form (s-FRQ). When individually expressed, each form shows temperature compensated oscillations, but together they extend the temperature range for which temperature compensation is observed [133-135]. A recent kinetic model by Akman et al. [136] describes the temperature-induced two FRQ isoforms and the associated temperature compensation not only for the $b d$ mutant, but also for $f r q^{l}, f r q^{7}$ and $f r q^{S 513 I}$ mutants.

As already mentioned above, the expressed FRQ-protein (i.e., both the s- and 1-form) is post-translationally modified by a variety of kinases as well as phosphatases leading to a finetuned stability of the protein, which regulates the period of Neurospora's circadian rhythm [63]. Casein Kinase 2 (CK2) has been found to be a key regulator of temperature compensation in Neurospora [94]. The chrono and period-3 mutations have be found to be within the $\beta 1$ and $\alpha$ subunits of CK2. Reducing the dose of these subunits, signifcantly alters temperature compensation indicating that temperature compensation is due to a balancing of positive and negative contributions to the period [137].

Besides regulating FRQ-protein stability by proteasomal degradation [67], there is now evidence that frq-mRNA is regulated by the Exosome and defining an additional posttranscriptional negative feedback loop [138].

FRQ dimerizes by a coiled-coil domain, which is important for maintaining circadian rhythmicity [139]. FRQ also binds to a "FRQ-interacting RNA helicase", FRH [140]. Downregulation of FRH using RNA interference has been found to lead to increased frq-mRNA levels indicating that FRH is important in the negative loop of Neurospora's clock mechanism [72].

When transferring cultures from darkness to continuous light conditions, the circadian rhythm is abolished, frq-mRNA and FRQ-protein levels reach a steady state (after partial adaptation responses) and growth tubes show constant conidiation [120,141, 142]. The light resetting behavior of the Neurospora clock which has been characterized by several groups is well described by a Goodwin oscillator using the assumption that light overrides the inhibitory effect of FRQ on its own transcription and increases frq transcription [143]. VIVID (VVD) is another light-upregulated and light-responsive protein, which contains a blue light receptor [144146]. The role of VVD is associated with the control of the phase of Neuropsora's circadian rhythm, its light resetting and transient light response [144, 147-149] as well as in the temperature compensation of the circadian phase [150]. In the $v v d^{K O}$ the phosphorylation pattern of FRQ is altered. At DD4 more of the lower-phosphorylated forms are seen in $v v d^{K O}$ while in the wild-type strain FRQ is hyperphosphorylated [150] indicating that VVD somehow interacts with FRQ and/or FRQ-phosphorylating or dephosphorylating processes. Schneider et al. [151] have recently found that a $v v d$ mutant strain can show rhythmic conidiation under constant light (LL) condition. The period of this strain ranges between 6 to $21 \mathrm{hr}$ in LL dependent upon the light intensity, the carbon source in the medium and the presence of other mutations. The rhythms in LL require the wc-1 genes, but not the frq gene and FRQ does not show oscillations. Schneider et al. [151] therefore conclude that the conidiation rhythm observed in LL in the $v v d$ strain is driven by an oscillator independent of FRQ. 


\section{FRQ-independent oscillators}

Surprisingly, certain circadian or noncircadian oscillations do not seem to require a functional FRQ protein. They are often referred to as "FRQ-less oscillators" (FLOs) [152, 153]. The first strain containing a FLO, $f r q^{9}$, was characterized by Loros et al. [154]. In this strain a complete loss in temperature compensation in its conidiation rhythm was observed. This strain produces a short nonfunctional form of FRQ, and the observed phenotype, showing noncircadian banding appearing after a certain induction time, was confirmed using a true frq-knockout strain $\left(\right.$ frq $\left.^{10}\right)$ [155].

Several FLOs have now been identified, and alternative hypotheses for the 'circadian pacemaker' in Neurospora have been put forward [151, 152, 156-160]. Many of these FLOs lack one or more of the defining properties of circadian rhythms and are therefore noncircadian [31]. There is presently a disagreement whether some of the FLOs can be entrained by temperature cycles [161-163].

de Paula et al. [31,32] recently found a FLO, which shows circadian (i.e., temperature compensated) oscillations in the activity of the clock-controlled gene 16 (ccg-16) both in darkness as well as under continuous light conditions. The oscillator requires WC-1 and WC-2 and there is the possibility that this WC-FLO is involved in the generation of WC-1 rhythms.

When nitrate ion is the only nitrogen source, the nitrate assimilation pathway is turned on showing oscillations in nitrate reductase (NR) activity with a period length of approximately 24 hours [33]. These oscillations do not require a functional FRQ, but do require WC-1, and are observed both in darkness as well as under continuous light conditions. The 'nitrate FLO' contains a negative feedback loop, where the downstream product of NR, the NITROGEN METABOLITE REGULATOR (NMR) protein inhibits the transcription of nit-3 (the structural gene of NR) by binding to its transcription factor NIT-2 [164, 165]. The existence of such a nitrogen oscillator allows efficient nitrogen uptake at the phase when physiological activity is high.

\section{The Mammalian Circadian Clock}

The master clock

Today, the SCN is recognized not only to act as a central clock, but also as a synchronizer of circadian rhythmicity in other tissues [14]. It is now generally accepted that the retina measures the light intensity through a non-image photoreception and transmits this signal to the SCN. This is mediated by the pigment melanopsin [166], which is accepted as a major component in the synchronisation of circadian clocks.

The SCN has efferents to peripheral tissues, which constitutes a part of the sympathetic outflow from the brain to the kidneys, bladder, spleen, adrenal and thyroid glands, as well as to white and brown adipose tissue. The SCN is also involved in the parasympathetic nervous system with innervation of the liver, pancreas, thyroid and submandibular glands. Possibly, there is also a modulation of the neuroendocrine systems, as well [167]. In addition, secretion of melatonin from the pineal gland is regulated through nerve pulses from SCN, whereby the modulatory role of melatonin on the sleep/wake rhythms, blood pressure and other functions is effected via the blood stream $[12,14]$.

It has also been found that transforming growth factor alpha (TGF-alpha) functions as an output signal from the mammalian clock in the $\mathrm{SCN}$, mediated through the EGF receptors on the neurons in the hypothalamic subparaventricular zone in mice $[168,169]$. 


\section{The cellular clockwork}

There is now increasing evidence that clock genes are expressed in the oocyte and during early embryonic development [170]. The mammalian circadian clock is a complex autoregulatory transcriptional and translational feedback program, which is composed of positive and negative regulators [171]. Two basic helix-loop-helix transcription factors, CLOCK AND BMAL1, form a heterodimer, which constitute the positive elements and drive transcription of three Period (Per) and two Cryptochrome (Cry) genes (Fig. 4). In the nucleus, the heterodimers bind to E-box enhancer elements in the promoter regions of the genes encoding Per1, Per2, Per3, Cryl and Cry 2 and enhance transcription [172]. In intact animals transcription of Perl starts before dawn and has a peak in Perl-mRNA about 6 hours later. The levels then rapidly subside before the end of the day. The resulting peak of the PER1 protein comes 6 hours after its mRNA. Per3 transcripts accumulate at the beginning of the day and subside after 4-6 hours, while Per 2 mRNA accumulation occurs later than the two others and peaks at dusk. The transcripts of Cryl and Cry 2 reach a peak at 6 to 8 hours after dawn and thereafter decline. In contrast to the transcripts, the resulting proteins all oscillate with the same phasing and reach maximum levels at dusk. The PER

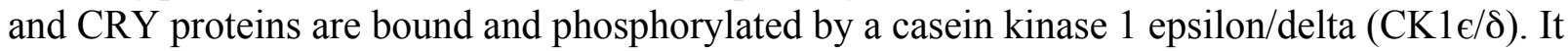
has been found that phosphorylation by $\mathrm{CK} 1 \epsilon / \delta$ is temperature-insensitive and perioddetermining [173], probably by an "instantaneous" [51] temperature compensation mechanism of the enzyme. In addition, PER and CRY proteins translocate to the nucleus and act as negative regulators, both of their own transcription and by directly interacting with the CLOCK-BMAL1 heterodimer. Their transcription is therefore inhibited during the night (see [171]). It has recently been found that CLOCK possesses intrinsic histone acetyltransferase activity in mouse liver cells, which contributes to chromatin-remodelling events related to circadian control of gene expression. In addition, CLOCK mediates acetylation of BMAL1, which serves as another regulatory element in the clock. Thereby, BMAL1 undergoes rhythmic acetylation in the liver, where the timing parallels the down-regulation of circadian transcription in clock-controlled genes [174].

At least two other proteins may modulate PER1 activity in mammalian cells by regulating the circadian periodicity [175]. In addition, Rev-erb- $\alpha$ modulates the clock by prolonging the periodicity and also coordinating metabolic pathways [176]. Light then resets the master clock in the SCN, where the pigment melanopsin plays a central role [166]. However, the effect is depending on the time when it acts, causing both phase shift and modulation of the circadian phase $[166,177]$. In addition, at least two different types of microRNA exist which are interacting with the CLOCK-BMAL1 complex, whereby the circadian period is lengthened and the entrainment of the master clock by light is attenuated [176].

\section{Peripheral clocks}

The cloning and characterization of mammalian clock genes has revealed that they are generally expressed in a circadian manner in almost all organs of the body [178]. For nearly 30 years it has been known that the rate of cell proliferation undergoes substantial circadian variations, where the phasing differs from tissue to tissue. It has been shown that the molecular circadian clock exerts a direct control on the cell division cycle in proliferating tissues by modulating the activity of cyclins and cyclin dependent kinases [179]. Still, it is not clear what 
causes the phase delay in some tissues. On the other hand, rhythms of body temperature in rodents can sustain peripheral circadian clocks, being an indirect mechanism for phase synchronisation [180]. Peripheral clocks appear also important for the regulation of cardiovascular and metabolic functions [181].

Since the 1980s numerous reports have described cyclic variations in different parts of hemopoiesis, both in the maturing compartments of the bone marrow and in the relative numbers of different types of leukocytes in peripheral blood [182-187]. It has been postulated that the whole immune system is both exogenously regulated and controlled by the endogenous clock from SCN [188]. In particular, BMAL1 seems to be important for the development of B cells along a circadian time scale [189]. In line with this, it has recently been reported that the circadian expression of monocyte chemoattractant protein-1 (MCP-1/JE), which is important for the phagocytic functions in macrophages, is directly controlled by BMAL1 [190].

\section{Stem cells}

Several years ago, it was shown that the clonability of murine progenitor cells underwent circadian variations when cultured in semisolid medium [191-194]. These variations were synchronous with the proliferative activity of the bone marrow, indicating a general systemic regulation of hemopoiesis. Later, it was shown that the different clock genes were not only expressed in hemopoietic stem cells in mice [195], but also appeared to be developmentally regulated [196]. Subsequent sampling of human stem and progenitor cells (CD34+) from the bone marrow showed a different pattern, both with regard to phasing and amplitude [197]. Maximum mRNA level for Per1, Per 2 and Cry 2 were found during the morning, whereas Reverb $\alpha$, Bmall and Clock did not show significant circadian variations.

Recently, it has been found that hemopoietic cell trafficking is due to regulated adhesion and attraction to the bone marrow microenvironment [198]. In line with this it was reported that hemopoietic stem cell release in mice is regulated through circadian oscillations, peaking at 5 hours after the initiation of light, and reaching a nadir at 5 hours after darkness [199].

Cultured human mesenchymal stem cells from the bone marrow can show circadian rhythms using serum shock [200-202] and cAMP analogs. The phosphorylation status of both PER1 and GSK3 $\beta$ was essential for getting circadian rhythms [203]. Since such stem cells are essential for normal hemopoiesis to take place in vivo, this appears to be a promising model for studying molecular networks related to the circadian clocks.

\section{Cell culture studies}

During the last decade circadian oscillations have also been observed in mammalian cells from peripheral tissues, and mainly in murine and rat fibroblasts (for review, see [204]). It was shown that serum shock induced the circadian expression of various clock genes both in fibroblasts and hepatoma cells from rats [202]. Later it was shown that cAMP, protein kinase C, glucocorticoid hormones and $\mathrm{Ca}^{2+}$ had the same effect [200]. Surprisingly, it was found that multiple signaling pathways in the cells could elicit circadian gene expression [201].

Importantly, the induction of circadian rhythms in clock gene expression in fibroblasts in vitro did not have any relation to the proliferative activity in general.

It has been found that the cycling of cryptochromes appear not necessary for circadian clock functions in mouse fibroblasts [205], challenging the view of a transcriptional-translational feedback loop in which the cycling of the CRY1 and CRY2 is thought to be necessary (Fig. 4). Hence, there may be a certain redundancy in the factors participating in circadian cycling, or there are individual differences between various differentiated cell types [206]. 


\section{The plant circadian clock \\ Background}

Circadian components in important processes as flowering and other daylength-dependent physiological phenomena were early recognized [207]. Circadian rhythms in $\mathrm{CO}_{2}$ exchange [208, 209], enzyme activities, and transcript levels were since reported (for reviews see [10, 210, 211]). Recently, circadian rhythms in chromatin structure were observed in plants [212].

One of the most extensively studied gene families in plants, the $C A B$ genes (CHLOROPHYLL A/B-BINDING PROTEIN), was shown to be expressed in a circadian manner, and also to be induced by light in many different plants including the model plant Arabidopsis [213-216]. These genes are encoded in the nucleus, translated in the cytosol, and then the proteins are imported into the chloroplasts to become components of the photosynthesis apparatus. Based on the properties of the $C A B$ promoter, a pioneering method for picking clock mutants was developed [217]. A fragment of the $C A B$ promoter, which was essential for light and circadian expression, was coupled to a luciferase reporter gene, and transformed into Arabidopsis. These transgenic Arabidopsis lines were then used to select for mutants in $C A B$ rhythms recorded by fluorescence. A short period mutant, tocl (timing of $c a b$ 1), was identified and further characterized. In $t o c 1$ plants the fluorescence rhythm linked to the $C A B$ promoter was shortened to $20.9 \mathrm{~h}$, whereas control plants showed a period length of 24.7. The rhythm in leaf movement also showed a shorter period $(23.3 \mathrm{~h})$ in the tocl mutant, compared with control plants $(25.2 \mathrm{~h})$. The TOC1 gene was later cloned, and identified [218] as a gene encoding a PPR protein (pseudoresponse regulator protein). TOC1 (or PPRl) is member of a small gene family in plants, comprising PPR1, PPR3, PPR5, PPR7, and PPR9, with partly overlapping functions. These proteins are reminiscent of the prokaryotic two-component kinases. They have a receiver domain containing a histidine, but the phospho-accepting aspartate residue present in prokaryotic twocomponents kinases is absent, suggesting that they do not function as the usual phospho-transfer proteins [219]. Further investigations showed that all five $P P R$ genes were important for the clock functions [220, 221].

\section{TOC1, LHY and CCA1 are essential elements in a plant clock mechanism}

It is now well established that expression of TOC1 is influenced by a feedback loop comprising two closely related MYB factors CCA1 (CIRCADIAN CLOCK ASSOCIATED 1) and LHY (LATE ELONGATED HYPOCOTYL) in addition to TOC1 itself [222]. In this loop TOC1 acts as a positive regulator of $C C A 1$ and $L H Y$ expression, whereas CCA1 and LHY act to inhibit TOC1 expression. CCA1 and $L H Y$ bind to the promoter of $T O C 1$, and thereby repress transcription of TOC1. The mechanism by which TOC1 promotes expression of CCA1 and LHY is not clear, but probably involves another protein, PIF3 (PHYTOCHROME INTERACTING FACTOR) [223, 224]. The mutual influence of TOC1 and CCA1/LHY have been well established through mutants, double mutants, and over-expressors. The results all support a regulatory model consistent with the positive and negative components of a feedback loop (Fig. 5) (for reviews see: $[212,220,225,226]$. However, TOC1 alone cannot induce expression of CCA1 and LHY. Other

genes are also necessary, i.e. GI, ELF4 and $L U X$. The number of genes known to be related to the $T O C-C C A 1 / L H Y$ feedback loop is increasing, and a list of 20 genes was presented in a recent review by McClung [220]. 
Cryptochromes are the only conserved genes that appear to be commonly involved in eukaryotic clocks, i.e. in Drosophila, mammals and plants [227]. In plants, cryptochromes among other photoreceptors, are important for light-input to the clock. However, as for mammals, the cryptochromes are not essential for the plant core clock mechanism because in the cry 1 cry 2 double knockout $C A B$ expression was still circadian, although the period length was extended [228].

Changes in chromatin structure, are another emerging common feature of eukaryotic clocks. Recently circadian chromatin changes were also found in plants. Chromatin immunoprecipitation (ChiP) assays were performed with an antiacetylated Histones 3 antibody ( $\alpha \mathrm{ACH} 3$ ), and subsequent PCR analysis of the TOC1 promoter [229]. The results showed that histones bound to the TOC1 promoter were acetylated in a circadian manner. The FACT (facilitates chromatin transcription) complex was also found to bind to the TOC1 promoter in a circadian manner, further confirming the chromatin remodeling in parallel with TOC1 expression [229].

Recently is has also been shown for Arabidopsis that phosphorylation and degradation of the TOC1 protein is important for clock function [221].

The balancing hypothesis for temperature compensation (see above) is supported by experiments showing that temperature compensation is achieved due to a dynamic balance between the genes $G I$ and $L H Y$ [230]. These findings have also been confirmed by numerical simulations using an interlocking-loop model [231, 232] showing that balancing LHY against GI and other evening-expressed genes can largely account for temperature compensation in wildtype plants and the temperature-specific phenotypes of GI mutants.

\section{Conclusion}

Circadian oscillators have evolved to adapt organisms to our planet's day/night cycles and to anticipate and meet unfavorable seasons. The core circadian oscillators are based on transcriptional-translational negative feedback loops and we are starting to understand and model the behaviors of the main molecular players within these oscillators and environmental influences. While transcriptional-translational negative feedback loops together with certain kinases and phosphatases appear to be conserved control structures among different organisms, the clock proteins are much more diverse and appear to have evolved independently.

\section{Acknowledgment}

We thank the referees for valuable comments. Due to space limitations we were not able to include in-depth discussions of certain topics, such as the model system Drosophila or the roles certain kinases and phosphatases appear to play within the various circadian oscillators. We regret that such and other important work has not been mentioned or cited. This work has been supported in part by a grant from Helse Vest, Norway. 


\section{References}

1 Bretzl, H. (1903) Botanische Forschungen des Alexanderzuges. B. G. Teubner, Leipzig

2 Eastman, C. R. (1904) THEOPHRASTUS REDIVIVUS. Science. 20, 727-728

3 de Mairan, J. (1729) Observation Botanique. Histoire de l' Academie Royale des Sciences, 35-36

4 Zinn, J. G. (1759) Von dem Schlafe der Pflanzen. Hambg. Mag. 22, 40-50

5 Freer, S. (2005) Linnaeus' Philosophia Botanica. Oxford University Press, New York

6 Reinberg, A. E., Lewy, H. and Smolensky, M. (2001) The birth of chronobiology: Julien Joseph Virey 1814. Chronobiol Int. 18, 173-186

7 Bünning, E. (1977) Fifty years of research in the wake of Wilhelm Pfeffer. Annu Rev Plant Physiol. 28, 1-22

$8 \quad$ Szymanksi, J. S. (1914) Eine Methode zur Untersuchung der Ruhe- und Aktivitätsperioden bei Tieren. Pflügers Archiv European Journal of Physiology. 158, 343385

9 Bünning, E. (1987) Rückblick: Warum der Einstieg in die selbstständige naturwissenschaftliche Forschung in früheren Jahrzehnten leichter war. Ber. Dt. Bot. Ges. 100, 415-419

10 Bünning, E. (1963) The physiological clock. Springer-Verlag, Berlin

11 Kondo, T. (2007) A cyanobacterial circadian clock based on the Kai oscillator. Cold Spring Harb Symp Quant Biol. 72, 47-55

12 Dunlap, J. C., Loros, J. J. and DeCoursey, P. J., eds. (2003) Biological timekeeping. Sinauer Associates, Inc. Publishers, Sunderland

13 Edmunds, L. N. (1988) Cellular and molecular bases of biological clocks. SpringerVerlag, New York

14 Koukkari, W. L. and Sothern, R. B. (2006) Introducing Biological Rhythms. Springer, New York

15 Kuhlman, S. J., Mackey, S. R. and Duffy, J. F. (2007) Biological Rhythms Workshop I: introduction to chronobiology. Cold Spring Harb Symp Quant Biol. 72, 1-6

16 Moore-Ede, M. C., Sulzman, F. M. and Fuller, C. A. (1982) The Clocks That Time Us. Physiology of the Circadian Timing System. Harvard University Press, Cambridge

17 Loudon, A. S., Semikhodskii, A. G. and Crosthwaite, S. K. (2000) A brief history of circadian time. Trends Genet. 16, 477-481

18 Konopka, R. J. and Benzer, S. (1971) Clock mutants of Drosophila melanogaster. Proc Natl Acad Sci U S A. 68, 2112-2116

19 Feldman, J. F. and Hoyle, M. N. (1973) Isolation of circadian clock mutants of Neurospora crassa. Genetics. 75, 605-613

20 Moore, R. Y. and Eichler, V. B. (1972) Loss of a circadian adrenal corticosterone rhythm following suprachiasmatic lesions in the rat. Brain Res. 42, 201-206

21 Stephan, F. K. and Zucker, I. (1972) Circadian rhythms in drinking behavior and locomotor activity of rats are eliminated by hypothalamic lesions. Proc Natl Acad Sci U S A. 69, 1583-1586

22 Ralph, M. R., Foster, R. G., Davis, F. C. and Menaker, M. (1990) Transplanted suprachiasmatic nucleus determines circadian period. Science. 247, 975-978

23 Kuhlman, S. J. (2007) Biological Rhythms Workshop IB: neurophysiology of SCN pacemaker function. Cold Spring Harb Symp Quant Biol. 72, 21-33

24 Zeng, H., Hardin, P. E. and Rosbash, M. (1994) Constitutive overexpression of the Drosophila period protein inhibits period mRNA cycling. EMBO J. 13, 3590-3598 
25 Aronson, B. D., Johnson, K. A., Loros, J. J. and Dunlap, J. C. (1994) Negative feedback defining a circadian clock: autoregulation of the clock gene frequency. Science. 263, 1578-1584.

26 Dunlap, J. C. (1999) Molecular bases for circadian clocks. Cell. 96, 271-290

27 Loros, J. J., Dunlap, J. C., Larrondo, L. F., Shi, M., Belden, W. J., Gooch, V. D., Chen, C. H., Baker, C. L., Mehra, A., Colot, H. V., Schwerdtfeger, C., Lambreghts, R., Collopy, P. D., Gamsby, J. J. and Hong, C. I. (2007) Circadian output, input, and intracellular oscillators: insights into the circadian systems of single cells. Cold Spring Harb Symp Quant Biol. 72, 201-214

28 Dunlap, J. C., Loros, J. J., Colot, H. V., Mehra, A., Belden, W. J., Shi, M., Hong, C. I., Larrondo, L. F., Baker, C. L., Chen, C. H., Schwerdtfeger, C., Collopy, P. D., Gamsby, J. J. and Lambreghts, R. (2007) A circadian clock in Neurospora: how genes and proteins cooperate to produce a sustained, entrainable, and compensated biological oscillator with a period of about a day. Cold Spring Harb Symp Quant Biol. 72, 57-68

29 Rosbash, M., Bradley, S., Kadener, S., Li, Y., Luo, W., Menet, J. S., Nagoshi, E., Palm, K., Schoer, R., Shang, Y. and Tang, C. H. (2007) Transcriptional feedback and definition of the circadian pacemaker in Drosophila and animals. Cold Spring Harb Symp Quant Biol. 72, 75-83

30 Rosbash, M., Allada, R., McDonald, M., Peng, Y. and Zhao, J. (2003) Circadian rhythms in Drosophila. Novartis Found Symp. 253, 223-232; discussion 252-225, 102-229, 232227 passim

31 de Paula, R. M., Vitalini, M. W., Gomer, R. H. and Bell-Pedersen, D. (2007) Complexity of the Neurospora crassa circadian clock system: multiple loops and oscillators. Cold Spring Harb Symp Quant Biol. 72, 345-351

32 de Paula, R. M., Lewis, Z. A., Greene, A. V., Seo, K. S., Morgan, L. W., Vitalini, M. W., Bennett, L., Gomer, R. H. and Bell-Pedersen, D. (2006) Two circadian timing circuits in Neurospora crassa cells share components and regulate distinct rhythmic processes. J Biol Rhythms. 21, 159-168

33 Christensen, M. K., Falkeid, G., Loros, J. J., Dunlap, J. C., Lillo, C. and Ruoff, P. (2004) A nitrate-induced frq-less oscillator in Neurospora crassa. J Biol Rhythms. 19, 280-286

34 Correa, A., Lewis, Z. A., Greene, A. V., March, I. J., Gomer, R. H. and Bell-Pedersen, D. (2003) Multiple oscillators regulate circadian gene expression in Neurospora. Proc Natl Acad Sci U S A. 100, 13597-13602

35 Cyran, S. A., Buchsbaum, A. M., Reddy, K. L., Lin, M. C., Glossop, N. R., Hardin, P. E., Young, M. W., Storti, R. V. and Blau, J. (2003) vrille, Pdpl, and dClock form a second feedback loop in the Drosophila circadian clock. Cell. 112, 329-341

36 Yu, W., Nomura, M. and Ikeda, M. (2002) Interactivating feedback loops within the mammalian clock: BMAL1 is negatively autoregulated and upregulated by CRY1, CRY2, and PER2. Biochemical \& Biophysical Research Communications. 290, 933-941

37 Roenneberg, T., Chua, E. J., Bernardo, R. and Mendoza, E. (2008) Modelling biological rhythms. Curr Biol. 18, R826-R835

38 Winfree, A. T. (2000) The geometry of biological time. Second edition. Springer-Verlag, New York

39 Murray, J. D. (1993) Mathematical Biology. Springer-Verlag, Berlin

40 Goodwin, B. C. (1965) Oscillatory behavior in enzymatic control processes. Advances in enzyme regulation. $3,425-438$ 
41 Goodwin, B. C. (1997) Temporal organization and disorganization in organisms. Chronobiol Int. 14, 531-536

42 Ruoff, P. and Rensing, L. (1996) The temperature-compensated Goodwin model simulates many circadian clock properties. J. Theoret. Biol. 179, 275-285

43 Goldbeter, A. (1995) A model for circadian oscillations in the Drosophila period protein (PER). Proceedings of the Royal Society of London, Series B: Biological Sciences. 261, 319-324

44 Leloup, J. C., Gonze, D. and Goldbeter, A. (1999) Limit cycle models for circadian rhythms based on transcriptional regulation in Drosophila and Neurospora. J Biol Rhythms. 14, 433-448.

45 Leloup, J. C. and Goldbeter, A. (2003) Toward a detailed computational model for the mammalian circadian clock. Proc Natl Acad Sci U S A. 100, 7051-7056

46 Leloup, J. C. and Goldbeter, A. (2001) A molecular explanation for the long-term suppression of circadian rhythms by a single light pulse. American Journal of Physiology - Regulatory Integrative \& Comparative Physiology. 280, R1206-1212

47 Leloup, J. C. and Goldbeter, A. (2000) Modeling the molecular regulatory mechanism of circadian rhythms in Drosophila. Bioessays. 22, 84-93

48 Leloup, J. C. and Goldbeter, A. (1999) Chaos and birhythmicity in a model for circadian oscillations of the PER and TIM proteins in Drosophila. J. Theoret. Biol. 198, 445-459

49 Leloup, J. C. and Goldbeter, A. (1997) Temperature compensation of circadian rhythms: control of the period in a model for circadian oscillations of the per protein in Drosophila. Chronobiol Int. 14, 511-520

50 Ruoff, P., Zakhartsev, M. and Westerhoff, H. V. (2007) Temperature compensation through systems biology. Febs J. 274, 940-950

51 Ruoff, P., Vinsjevik, M. and Rensing, L. (2000) Temperature compensation in biological oscillators: A challenge for joint experimental and theoretical analysis. Comments Theor. Biol. 5, 361-382

52 Ruoff, P., Rensing, L., Kommedal, R. and Mohsenzadeh, S. (1997) Modeling temperature compensation in chemical and biological oscillators. Chronobiol Int. 14, 499-510 Ruoff, P., Loros, J. J. and Dunlap, J. C. (2005) The relationship between FRQ-protein stability and temperature compensation in the Neurospora circadian clock. Proc Natl Acad Sci U S A. 102, 17681-17686

54 Ruoff, P. (1992) Introducing temperature-compensation in any reaction kinetic oscillator model. J. Interdiscipl. Cycle Res. 23, 92-99

55 Rensing, L. and Ruoff, P. (2002) Temperature effect on entrainment, phase shifting, and amplitude of circadian clocks and its molecular bases. Chronobiol Int. 19, 807-864

56 Rensing, L., Mohsenzadeh, S., Ruoff, P. and Meyer, U. (1997) Temperature compensation of the circadian period length--a special case among general homeostatic mechanisms of gene expression? Chronobiol Int. 14, 481-498

57 Kurosawa, G. and Iwasa, Y. (2005) Temperature compensation in circadian clock models. J Theor Biol. 233, 453-468

58 Hong, C. I. and Tyson, J. J. (1997) A proposal for temperature compensation of the circadian rhythm in Drosophila based on dimerization of the PER protein. Chronobiol Int. 14, 521-529

59 Gonze, D., Leloup, J. C. and Goldbeter, A. (2000) Theoretical models for circadian rhythms in Neurospora and Drosophila. C R Acad Sci III. 323, 57-67. 
Ruoff, P., Mohsenzadeh, S. and Rensing, L. (1996) Circadian rhythms and protein turnover: the effect of temperature on the period lengths of clock mutants simulated by the Goodwin oscillator. Naturwissenschaften. 83, 514-517

61 Gorl, M., Merrow, M., Huttner, B., Johnson, J., Roenneberg, T. and Brunner, M. (2001) A PEST-like element in FREQUENCY determines the length of the circadian period in Neurospora crassa. EMBO Journal. 20, 7074-7084

62 Liu, Y., Loros, J. and Dunlap, J. C. (2000) Phosphorylation of the Neurospora clock protein FREQUENCY determines its degradation rate and strongly influences the period length of the circadian clock. Proc Natl Acad Sci U S A. 97, 234-239.

63 Baker, C. L., Kettenbach, A. N., Loros, J. J., Gerber, S. A. and Dunlap, J. C. (2009) Quantitative proteomics reveals a dynamic interactome and phase-specific phosphorylation in the Neurospora circadian clock. Mol Cell. 34, 354-363

64 Mehra, A., Shi, M., Baker, C. L., Colot, H. V., Loros, J. J. and Dunlap, J. C. (2009) A role for casein kinase 2 in the mechanism underlying circadian temperature compensation. Cell. 137, 749-760

65 He, Q., Cha, J., He, Q., Lee, H. C., Yang, Y. and Liu, Y. (2006) CKI and CKII mediate the FREQUENCY-dependent phosphorylation of the WHITE COLLAR complex to close the Neurospora circadian negative feedback loop. Genes Dev. 20, 2552-2565 He, Q., Cheng, P., Yang, Y., Yu, H. and Liu, Y. (2003) FWD1-mediated degradation of FREQUENCY in Neurospora establishes a conserved mechanism for circadian clock regulation. EMBO J. 22, 4421-4430

67 He, Q. and Liu, Y. (2005) Degradation of the Neurospora circadian clock protein FREQUENCY through the ubiquitin-proteasome pathway. Biochem Soc Trans. 33, 953956

68 Mayer, J., Ciechanover, A. and Rechsteiner, M., eds. (2005) Protein Degradation. Wiley$\mathrm{VCH}$, Weinheim

69 Liu, Y. and Bell-Pedersen, D. (2006) Circadian rhythms in Neurospora crassa and other filamentous fungi. Eukaryot Cell. 5, 1184-1193

70 Heintzen, C. and Liu, Y. (2007) The Neurospora crassa circadian clock. Adv Genet. 58, 25-66

71 Querfurth, C., Diernfellner, A., Heise, F., Lauinger, L., Neiss, A., Tataroglu, O., Brunner, M. and Schafmeier, T. (2007) Posttranslational regulation of Neurospora circadian clock by CK1a-dependent phosphorylation. Cold Spring Harb Symp Quant Biol. 72, 177-183

72 Cha, J., Huang, G., Guo, J. and Liu, Y. (2007) Posttranslational control of the Neurospora circadian clock. Cold Spring Harb Symp Quant Biol. 72, 185-191

73 Loudon, A. S., Meng, Q. J., Maywood, E. S., Bechtold, D. A., Boot-Handford, R. P. and Hastings, M. H. (2007) The biology of the circadian Ck1epsilon tau mutation in mice and Syrian hamsters: a tale of two species. Cold Spring Harb Symp Quant Biol. 72, 261-271 Virshup, D. M., Eide, E. J., Forger, D. B., Gallego, M. and Harnish, E. V. (2007) Reversible protein phosphorylation regulates circadian rhythms. Cold Spring Harb Symp Quant Biol. 72, 413-420

75 Blau, J. and Young, M. W. (1999) Cycling vrille expression is required for a functional Drosophila clock. Cell. 99, 661-671

76 Glossop, N. R., Houl, J. H., Zheng, H., Ng, F. S., Dudek, S. M. and Hardin, P. E. (2003) VRILLE feeds back to control circadian transcription of Clock in the Drosophila circadian oscillator. Neuron. 37, 249-261 
77 Glossop, N. R., Lyons, L. C. and Hardin, P. E. (1999) Interlocked feedback loops within the Drosophila circadian oscillator. Science. 286, 766-768

78 Benito, J., Zheng, H., Ng, F. S. and Hardin, P. E. (2007) Transcriptional feedback loop regulation, function, and ontogeny in Drosophila. Cold Spring Harb Symp Quant Biol. 72, 437-444

79 Tsai, T. Y., Choi, Y. S., Ma, W., Pomerening, J. R., Tang, C. and Ferrell, J. E., Jr. (2008) Robust, tunable biological oscillations from interlinked positive and negative feedback loops. Science. 321, 126-129

80 Smolen, P., Baxter, D. A. and Byrne, J. H. (2003) Reduced models of the circadian oscillators in Neurospora crassa and Drosophila melanogaster illustrate mechanistic similarities. Omics. 7, 337-354

81 Smolen, P., Baxter, D. A. and Byrne, J. H. (2002) A reduced model clarifies the role of feedback loops and time delays in the Drosophila circadian oscillator. Biophys J. 83, 2349-2359

82 Cote, G. G. and Brody, S. (1986) Circadian rhythms in Drosophila melanogaster: analysis of period as a function of gene dosage at the per (period) locus. J Theor Biol. 121, 487503

83 Ruoff, P., Christensen, M. K. and Sharma, V. K. (2005) PER/TIM-mediated amplification, gene dosage effects and temperature compensation in an interlockingfeedback loop model of the Drosophila circadian clock. J Theor Biol. 237, 41-57

84 Smith, R. F. and Konopka, R. J. (1982) Effects of Dosage Alterations at the per Locus on the Period of the Circadian Clock of Drosophila. Mol. Gen. Genet. 185, 30-36

85 Goldbeter, A. (1996) Biochemical Oscillations and Cellular Rhythms: The Molecular Bases of Periodic and Chaotic Behavior. Cambridge University Press, Cambridge, UK

86 Goldbeter, A. (2002) Computational approaches to cellular rhythms. Nature. 420, 238-245

87 Field, R. J. and Burger, M. (1985) Oscillations and Traveling Waves in Chemical Systems. John Wiley \& Sons, New York

88 Epstein, I. R. and Pojman, J. A., eds. (1998) An Introduction to Nonlinear Chemical Dynamics: Oscillations, Waves, Patterns, and Chaos. Oxford University Press, New York

89 Field, R. J. and Györgyi, L., eds. (1993) Chaos in Chemistry and Biochemistry. World Sci., Singapore

90 Higgins, J. (1967) The theory of oscillating reactions. Industrial and Engineering Chemistry. 59, 18-62

91 Noyes, R. M. (1983) Oscillatory reaction. In McGraw-Hill Encyclopedia of Chemistry (Parker, S. P., ed.). pp. 716-718, McGraw Hill Book Company, New York

92 De Kepper, P. and Boissonade, J. (1985) From Bistability to Sustained Oscillations in Homogeneous Chemical Systems in Flow Reactor Mode. In Oscillations and Traveling Waves in Chemical Systems (Field, R. J. and Burger, M., eds.). pp. 223-256, John Wiley \& Sons, New York

93 Nakajima, M., Imai, K., Ito, H., Nishiwaki, T., Murayama, Y., Iwasaki, H., Oyama, T. and Kondo, T. (2005) Reconstitution of circadian oscillation of cyanobacterial KaiC phosphorylation in vitro. Science. 308, 414-415

94 Mehra, A., Hong, C. I., Shi, M., Loros, J. J., Dunlap, J. C. and Ruoff, P. (2006) Circadian rhythmicity by autocatalysis. PLoS Comput Biol. 2, e96

95 Ross, J., Schreiber, I. and Vlad, M. O. (2006) Determination of Complex Reaction Mechanisms. Analysis of

Chemical, Biological and Genetic Networks. Oxford University Press, Oxford 
96 Tigges, M., Marquez-Lago, T. T., Stelling, J. and Fussenegger, M. (2009) A tunable synthetic mammalian oscillator. Nature. 457, 309-312

97 Franck, U. F. (1980) Feedback Kinetics in Physicochemical Oscillators. Ber. Bunsenges. Phys. Chem. 84, 334-341

98 Kóvacs, K. M., Rábai, G. (2002) Temperature-compensation in pH-oscillators. Phys. Chem. Chem. Phys. 4, 5265-5269

99 Rábai, G. and Hanazaki, I. (1999) Temperature Compensation in the Oscillatory Hydrogen Peroxide-Thiosulfate-Sulfite Flow System. Chem. Comm., 1965-1966

100 Hastings, J. W. and Sweeney, B. M. (1957) On the mechanism of temperature independence in a biological clock. Proc Natl Acad Sci U S A. 43, 804-811

101 Heinrich, R., Schuster, S. (1996) The regulation of cellular systems. Chapman and Hall, New York

102 Ruoff, P., Christensen, M. K., Wolf, J. and Heinrich, R. (2003) Temperature dependency and temperature compensation in a model of yeast glycolytic oscillations. Biophys Chem. 106, 179-192

103 Ruoff, P. (1994) General homeostasis in period and temperature-compensated chemical clock mutants by random selection conditions. Naturwissenschaften. 81, 456-459

104 Ruoff, P., Behzadi, A., Hauglid, M., Vinsjevik, M. and Havas, H. (2000) pH homeostasis of the circadian sporulation rhythm in clock mutants of Neurospora crassa. Chronobiol Int. 17, 733-750

105 Hong, C. I., Conrad, E. D. and Tyson, J. J. (2007) A proposal for robust temperature compensation of circadian rhythms. Proc Natl Acad Sci U S A. 104, 1195-1200

106 Ni, X. Y., Drengstig, T. and Ruoff, P. (2009) The control of the controller: molecular mechanisms for robust perfect adaptation and temperature compensation. Biophys J. 97, 1244-1253

107 Davis, R. H. (2000) Neurospora. Contributions of a model organism. Oxford University Press, New York

108 Bell-Pedersen, D., Crosthwaite, S. K., Lakin-Thomas, P. L., Merrow, M. and Okland, M. (2001) The Neurospora circadian clock: simple or complex? Philosophical Transactions of the Royal Society of London - Series B: Biological Sciences. 356, 1697-1709

109 Dunlap, J. C. and Loros, J. J. (2004) The Neurospora circadian system. J Biol Rhythms. 19, 414-424

110 Lakin-Thomas, P. L., Cote, G. G. and Brody, S. (1990) Circadian rhythms in Neurospora crassa: biochemistry and genetics. Critical Reviews in Microbiology. 17, 365-416

111 Loros, J. J. and Dunlap, J. C. (2001) Genetic and molecular analysis of circadian rhythms in Neurospora. Annu Rev Physiol. 63, 757-794

112 Pittendrigh, C. S., Bruce, V. G, Rosenzweig, N. S., Rubin, M. L. (1959) A biological clock in Neurospora. Nature. 184, 169-170

113 Morgan, L. W., Greene, A. V. and Bell-Pedersen, D. (2003) Circadian and light-induced expression of luciferase in Neurospora crassa. Fungal Genet Biol. 38, 327-332

114 Gooch, V. D., Mehra, A., Larrondo, L. F., Fox, J., Touroutoutoudis, M., Loros, J. J. and Dunlap, J. C. (2008) Fully codon-optimized luciferase uncovers novel temperature characteristics of the Neurospora clock. Eukaryot Cell. 7, 28-37

115 Shi, M., Larrondo, L. F., Loros, J. J. and Dunlap, J. C. (2007) A developmental cycle masks output from the circadian oscillator under conditions of choline deficiency in Neurospora. Proc Natl Acad Sci U S A. 104, 20102-20107 
116 Ballario, P. and Macino, G. (1997) White collar proteins: PASsing the light signal in Neurospora crassa. Trends Microbiol. 5, 458-462.

117 Ballario, P., Talora, C., Galli, D., Linden, H. and Macino, G. (1998) Roles in dimerization and blue light photoresponse of the PAS and LOV domains of Neurospora crassa white collar proteins. Molecular Microbiology. 29, 719-729

118 Ballario, P., Vittorioso, P., Magrelli, A., Talora, C., Cabibbo, A. and Macino, G. (1996) White collar-1, a central regulator of blue light responses in Neurospora, is a zinc finger protein. EMBO Journal. 15, 1650-1657

119 Bell-Pedersen, D., Dunlap, J. C. and Loros, J. J. (1996) Distinct cis-acting elements mediate clock, light, and developmental regulation of the Neurospora crassa eas (ccg-2) gene. Molecular \& Cellular Biology. 16, 513-521

120 Crosthwaite, S. K., Dunlap, J. C. and Loros, J. J. (1997) Neurospora wc-1 and wc-2: transcription, photoresponses, and the origins of circadian rhythmicity. Science. 276, 763769.

121 Froehlich, A. C., Liu, Y., Loros, J. J., Dunlap, J. C. (2002) White Collar-1, a circadian blue light photoreceptor, binding to the frequency promoter. Science. 297, 815-819

122 Linden, H. and Macino, G. (1997) White collar 2, a partner in blue-light signal transduction, controlling expression of light-regulated genes in Neurospora crassa. EMBO Journal. 16, 98-109

123 Cheng, P., Yang, Y., Wang, L., He, Q. and Liu, Y. (2003) WHITE COLLAR-1, a multifunctional Neurospora protein involved in the circadian feedback loops, light sensing, and transcription repression of wc-2. Journal of Biological Chemistry. 278, 38013808

124 He, Q., Cheng, P., Yang, Y., Wang, L., Gardner, K. H. and Liu, Y. (2002) White collar-1, a DNA binding transcription factor and a light sensor. Science. 297, 840-843

125 Froehlich, A. C., Loros, J. J. and Dunlap, J. C. (2003) Rhythmic binding of a WHITE COLLAR-containing complex to the frequency promoter is inhibited by FREQUENCY. Proc Natl Acad Sci U S A. 100, 5914-5919

126 Lee, K., Loros, J. J. and Dunlap, J. C. (2000) Interconnected feedback loops in the Neurospora circadian system.[erratum appears in Science 2000 Oct 13;290(5490):277]. Science. 289, 107-110

127 Hong, C. I., Jolma, I. W., Loros, J. J., Dunlap, J. C. and Ruoff, P. (2008) Simulating dark expressions and interactions of frq and wc-1 in the Neurospora circadian clock. Biophys J. 94, 1221-1232

128 Hong, C. I., Ruoff, P., Loros, J. J. and Dunlap, J. C. (2008) Closing the circadian negative feedback loop: FRQ-dependent clearance of WC-1 from the nucleus. Genes Dev. 22, 3196-3204

129 Diernfellner, A. C., Querfurth, C., Salazar, C., Hofer, T. and Brunner, M. (2009) Phosphorylation modulates rapid nucleocytoplasmic shuttling and cytoplasmic accumulation of Neurospora clock protein FRQ on a circadian time scale. Genes Dev. 23, 2192-2200

130 Cheng, P., Yang, Y. and Liu, Y. (2001) Interlocked feedback loops contribute to the robustness of the Neurospora circadian clock. Proc Natl Acad Sci U S A. 98, 7408-7413

131 Denault, D. L., Loros, J. J. and Dunlap, J. C. (2001) WC-2 mediates WC-1-FRQ interaction within the PAS protein-linked circadian feedback loop of Neurospora. EMBO J. 20, 109-117 
132 Belden, W. J., Loros, J. J. and Dunlap, J. C. (2007) Execution of the circadian negative feedback loop in Neurospora requires the ATP-dependent chromatin-remodeling enzyme CLOCKSWITCH. Mol Cell. 25, 587-600

133 Diernfellner, A., Colot, H. V., Dintsis, O., Loros, J. J., Dunlap, J. C. and Brunner, M. (2007) Long and short isoforms of Neurospora clock protein FRQ support temperaturecompensated circadian rhythms. FEBS Lett. 581, 5759-5764

134 Garceau, N. Y., Liu, Y., Loros, J. J. and Dunlap, J. C. (1997) Alternative initiation of translation and time-specific phosphorylation yield multiple forms of the essential clock protein FREQUENCY. Cell. 89, 469-476

135 Liu, Y., Garceau, N. Y., Loros, J. J. and Dunlap, J. C. (1997) Thermally regulated translational control of FRQ mediates aspects of temperature responses in the Neurospora circadian clock. Cell. 89, 477-486

136 Akman, O. E., Locke, J. C., Tang, S., Carre, I., Millar, A. J. and Rand, D. A. (2008) Isoform switching facilitates period control in the Neurospora crassa circadian clock. Mol Syst Biol. 4, 164

137 Virshup, D. M. and Forger, D. B. (2009) Keeping the beat in the rising heat. Cell. 137, 602-604

138 Guo, J., Cheng, P., Yuan, H. and Liu, Y. (2009) The exosome regulates circadian gene expression in a posttranscriptional negative feedback loop. Cell. 138, 1236-1246

139 Cheng, P., Yang, Y., Heintzen, C. and Liu, Y. (2001) Coiled-coil domain-mediated FRQFRQ interaction is essential for its circadian clock function in Neurospora. EMBO J. 20, 101-108

140 Cheng, P., He, Q., Wang, L. and Liu, Y. (2005) Regulation of the Neurospora circadian clock by an RNA helicase. Genes Dev. 19, 234-241

141 Collett, M. A., Garceau, N., Dunlap, J. C. and Loros, J. J. (2002) Light and clock expression of the Neurospora clock gene frequency is differentially driven by but dependent on WHITE COLLAR-2. Genetics. 160, 149-158

142 Crosthwaite, S. K., Loros, J. J. and Dunlap, J. C. (1995) Light-induced resetting of a circadian clock is mediated by a rapid increase in frequency transcript. Cell. 81, 10031012

143 Ruoff, P., Vinsjevik, M., Monnerjahn, C. and Rensing, L. (2001) The Goodwin model: simulating the effect of light pulses on the circadian sporulation rhythm of Neurospora crassa. J Theor Biol. 209, 29-42

144 Heintzen, C., Loros, J. J. and Dunlap, J. C. (2001) The PAS protein VIVID defines a clock-associated feedback loop that represses light input, modulates gating, and regulates clock resetting. Cell. 104, 453-464

145 Pando, M. P. and Sassone-Corsi, P. (2001) Molecular clocks. A vivid loop of light. Nature. 410, 311-313

146 Zoltowski, B. D., Schwerdtfeger, C., Widom, J., Loros, J. J., Bilwes, A. M., Dunlap, J. C. and Crane, B. R. (2007) Conformational switching in the fungal light sensor Vivid. Science. 316, 1054-1057

147 Schwerdtfeger, C. and Linden, H. (2001) Blue light adaptation and desensitization of light signal transduction in Neurospora crassa. Mol Microbiol. 39, 1080-1087

148 Shrode, L. B., Lewis, Z. A., White, L. D., Bell-Pedersen, D. and Ebbole, D. J. (2001) vvd is required for light adaptation of conidiation-specific genes of Neurospora crassa, but not circadian conidiation. Fungal Genet Biol. 32, 169-181 
149 Elvin, M., Loros, J. J., Dunlap, J. C. and Heintzen, C. (2005) The PAS/LOV protein VIVID supports a rapidly dampened daytime oscillator that facilitates entrainment of the Neurospora circadian clock. Genes Dev. 19, 2593-2605

150 Hunt, S. M., Elvin, M., Crosthwaite, S. K. and Heintzen, C. (2007) The PAS/LOV protein VIVID controls temperature compensation of circadian clock phase and development in Neurospora crassa. Genes Dev. 21, 1964-1974

151 Schneider, K., Perrino, S., Oelhafen, K., Li, S., Zatsepin, A., Lakin-Thomas, P. and Brody, S. (2009) Rhythmic Conidiation in Constant Light in Vivid Mutants of Neurospora crassa. Genetics. 181, 917-931

152 Lakin-Thomas, P. L. (2006) New models for circadian systems in microorganisms. FEMS Microbiol Lett. 259, 1-6

153 Iwasaki, H. and Dunlap, J. C. (2000) Microbial circadian oscillatory systems in Neurospora and Synechococcus: models for cellular clocks. Curr Opin Microbiol. 3, 189196

154 Loros, J. J., Richman, A. and Feldman, J. F. (1986) A recessive circadian clock mutation at the frq locus of Neurospora crassa. Genetics. 114, 1095-1110

155 Aronson, B. D., Johnson, K. A. and Dunlap, J. C. (1994) Circadian clock locus frequency: protein encoded by a single open reading frame defines period length and temperature compensation. Proceedings of the National Academy of Sciences of the United States of America. 91, 7683-7687

156 Granshaw, T., Tsukamoto, M. and Brody, S. (2003) Circadian rhythms in Neurospora crassa: farnesol or geraniol allow expression of rhythmicity in the otherwise arrhythmic strains frq10, wc-1, and wc-2. J Biol Rhythms. 18, 287-296

157 Lakin-Thomas, P. L. (1998) Choline depletion, frq mutations, and temperature compensation of the circadian rhythm in Neurospora crassa. J Biol Rhythms. 13, 268-277

158 Lakin-Thomas, P. L. (2000) Circadian rhythms: new functions for old clock genes. Trends Genet. 16, 135-142.

159 Lakin-Thomas, P. L. and Brody, S. (2000) Circadian rhythms in Neurospora crassa: lipid deficiencies restore robust rhythmicity to null frequency and white-collar mutants. Proc Natl Acad Sci U S A. 97, 256-261

160 Lombardi, L., Schneider, K., Tsukamoto, M. and Brody, S. (2007) Circadian rhythms in Neurospora crassa: clock mutant effects in the absence of a frq-based oscillator. Genetics. 175, 1175-1183

161 Merrow, M., Brunner, M. and Roenneberg, T. (1999) Assignment of circadian function for the Neurospora clock gene frequency. Nature. 399, 584-586

162 Pregueiro, A. M., Price-Lloyd, N., Bell-Pedersen, D., Heintzen, C., Loros, J. J. and Dunlap, J. C. (2005) Assignment of an essential role for the Neurospora frequency gene in circadian entrainment to temperature cycles. Proc Natl Acad Sci U S A. 102, 2210-2215

163 Merrow, M. and Roenneberg, T. (2007) Circadian entrainment of Neurospora crassa. Cold Spring Harb Symp Quant Biol. 72, 279-285

164 Marzluf, G. A. (2004) Multiple Fungal GATA Transcription Factors and Combinatorial Gene Regulation. In The Mycota (Esser, K., ed.). pp. 111-119, Springer-Verlag, Berlin

165 Caddik, M. X. (2004) Nitrogen Regulation in Mycelial Fungi. In The Mycota (Esser, K., ed.). pp. 349-368, Springer-Verlag, Berlin

166 Panda, S., Sato, T. K., Castrucci, A. M., Rollag, M. D., DeGrip, W. J., Hogenesch, J. B., Provencio, I. and Kay, S. A. (2002) Melanopsin (Opn4) requirement for normal lightinduced circadian phase shifting. Science. 298, 2213-2216 
167 Bartness, T. J., Song, C. K. and Demas, G. E. (2001) SCN efferents to peripheral tissues: implications for biological rhythms. J Biol Rhythms. 16, 196-204

168 Barinaga, M. (2001) A Time to Rest: Clock Signal Identified. Science. 294, 2453-2454

169 Morre, D. J., Chueh, P. J., Pletcher, J., Tang, X., Wu, L. Y. and Morre, D. M. (2002) Biochemical basis for the biological clock. Biochemistry. 41, 11941-11945

170 Seron-Ferre, M., Valenzuela, G. J. and Torres-Farfan, C. (2007) Circadian clocks during embryonic and fetal development. Birth Defects Res C Embryo Today. 81, 204-214

171 Lowrey, P. L. and Takahashi, J. S. (2000) Genetics of the mammalian circadian system: Photic entrainment, circadian pacemaker mechanisms, and posttranslational regulation. Annu Rev Genet. 34, 533-562

172 Yoo, S. H., Ko, C. H., Lowrey, P. L., Buhr, E. D., Song, E. J., Chang, S., Yoo, O. J., Yamazaki, S., Lee, C. and Takahashi, J. S. (2005) A noncanonical E-box enhancer drives mouse Period2 circadian oscillations in vivo. Proc Natl Acad Sci U S A. 102, 2608-2613

173 Isojima, Y., Nakajima, M., Ukai, H., Fujishima, H., Yamada, R. G., Masumoto, K.-h., Kiuchi, R., Ishida, M., Ukai-Tadenuma, M., Minami, Y., Kito, R., Nakao, K., Kishimoto, W., Yoo, S.-H., Shimomura, K., Takao, T., Takano, A., Kojima, T., Nagai, K., Sakaki, Y., Takahashi, J. S. and Ueda, H. R. (2009) CKI $/ \delta$-dependent phosphorylation is a temperature-insensitive, period-determining process in the mammalian circadian clock. Proc Natl Acad Sci U S A. 106, 15744-15749

174 Hirayama, J., Sahar, S., Grimaldi, B., Tamaru, T., Takamatsu, K., Nakahata, Y. and Sassone-Corsi, P. (2007) CLOCK-mediated acetylation of BMAL1 controls circadian function. Nature. 450, 1086-1090

175 Brown, S. A., Ripperger, J., Kadener, S., Fleury-Olela, F., Vilbois, F., Rosbash, M. and Schibler, U. (2005) PERIOD1-associated proteins modulate the negative limb of the mammalian circadian oscillator. Science. 308, 693-696

176 Curtis, A. M., Cheng, Y., Kapoor, S., Reilly, D., Price, T. S. and Fitzgerald, G. A. (2007) Circadian variation of blood pressure and the vascular response to asynchronous stress. Proc Natl Acad Sci U S A. 104, 3450-3455

177 Hirota, T. and Fukada, Y. (2004) Resetting mechanism of central and peripheral circadian clocks in mammals. Zoolog Sci. 21, 359-368

178 Balsalobre, A. (2002) Clock genes in mammalian peripheral tissues. Cell Tissue Res. 309, 193-199

179 Clairambault, J. (2006) Physiologically based modelling of circadian control on cell proliferation. Conf Proc IEEE Eng Med Biol Soc. 1, 173-176

180 Brown, S. A., Zumbrunn, G., Fleury-Olela, F., Preitner, N. and Schibler, U. (2002) Rhythms of mammalian body temperature can sustain peripheral circadian clocks. Curr Biol. 12, 1574-1583

181 Rudic, R. D., Curtis, A. M., Cheng, Y. and FitzGerald, G. (2005) Peripheral clocks and the regulation of cardiovascular and metabolic function. Methods Enzymol. 393, 524-539

182 Laerum, O. D. (1995) Hematopoiesis occurs in rhythms. Exp Hematol. 23, 1145-1147

183 Smaaland, R., Sothern, R. B., Laerum, O. D. and Abrahamsen, J. F. (2002) Rhythms in human bone marrow and blood cells. Chronobiol Int. 19, 101-127

184 Berger, J. (2006) Current progress in chronohematology. J. Appl. Biomed. 4, 111-114 185 Filipski, E., King, V. M., Etienne, M. C., Li, X., Claustrat, B., Granda, T. G., Milano, G., Hastings, M. H. and Levi, F. (2004) Persistent twenty-four hour changes in liver and bone marrow despite suprachiasmatic nuclei ablation in mice. Am J Physiol Regul Integr Comp Physiol. 287, R844-851 
186 Oishi, K., Sakamoto, K., Okada, T., Nagase, T. and Ishida, N. (1998) Humoral signals mediate the circadian expression of rat period homologue (rPer2) mRNA in peripheral tissues. Neurosci Lett. 256, 117-119

187 James, F. O., Boivin, D. B., Charbonneau, S., Belanger, V. and Cermakian, N. (2007) Expression of clock genes in human peripheral blood mononuclear cells throughout the sleep/wake and circadian cycles. Chronobiol Int. 24, 1009-1034

188 Fukuya, H., Emoto, N., Nonaka, H., Yagita, K., Okamura, H. and Yokoyama, M. (2007) Circadian expression of clock genes in human peripheral leukocytes. Biochem Biophys Res Commun. 354, 924-928

189 Berger, J. (2008) A two-clock model of circadian timing in the immune system of mammals. Pathol Biol (Paris). 56, 286-291

190 Sun, Y., Yang, Z., Niu, Z., Peng, J., Li, Q., Xiong, W., Langnas, A. N., Ma, M. Y. and Zhao, Y. (2006) MOP3, a component of the molecular clock, regulates the development of B cells. Immunology. 119, 451-460

191 Morse, D., Cermakian, N., Brancorsini, S., Parvinen, M. and Sassone-Corsi, P. (2003) No circadian rhythms in testis: Periodl expression is clock independent and developmentally regulated in the mouse. Mol Endocrinol. 17, 141-151

192 Stoney, P. J., Halberg, F. and Simpson, H. W. (1975) Circadian variation in colonyforming ability of presumably intact murine bone marrow cells. Chronobiologia. 2, 319323

193 Aardal, N. P. (1984) Circannual variations of circadian periodicity in murine colonyforming cells. Exp. Hematol. 12, 61-67

194 Sletvold, O. and Laerum, O. D. (1988) Multipotent stem cell (CFU-S) numbers and circadian variations in aging mice. Eur J Haematol. 41, 230-236

195 Smaaland, R., Laerum, O. D., Sothern, R. B., Sletvold, O., Bjerknes, R. and Lote, K. (1992) Colony-forming unit-granulocyte-macrophage and DNA synthesis of human bone marrow are circadian stage-dependent and show covariation. Blood. 79, 2281-2287

196 Tsinkalovsky, O., Rosenlund, B., Laerum, O. D. and Eiken, H. G. (2005) Clock gene expression in purified mouse hematopoietic stem cells. Exp Hematol. 33, 100-107

197 Tsinkalovsky, O., Filipski, E., Rosenlund, B., Sothern, R. B., Eiken, H. G., Wu, M. W., Claustrat, B., Bayer, J., Levi, F. and Laerum, O. D. (2006) Circadian expression of clock genes in purified hematopoietic stem cells is developmentally regulated in mouse bone marrow. Exp Hematol. 34, 1249-1261

198 Tsinkalovsky, O., Smaaland, R., Rosenlund, B., Sothern, R. B., Hirt, A., Steine, S., Badiee, A., Abrahamsen, J. F., Eiken, H. G. and Laerum, O. D. (2007) Circadian variations in clock gene expression of human bone marrow CD34+ cells. J Biol Rhythms. 22, $140-150$

199 Mendez-Ferrer, S., Chow, A., Merad, M. and Frenette, P. S. (2009) Circadian rhythms influence hematopoietic stem cells. Curr Opin Hematol. 16, 235-242

200 Balsalobre, A., Damiola, F. and Schibler, U. (1998) A serum shock induces circadian gene expression in mammalian tissue culture cells. Cell. 93, 929-937

201 Balsalobre, A., Marcacci, L. and Schibler, U. (2000) Multiple signaling pathways elicit circadian gene expression in cultured Rat-1 fibroblasts. Curr Biol. 10, 1291-1294

202 Nagoshi, E., Brown, S. A., Dibner, C., Kornmann, B. and Schibler, U. (2005) Circadian gene expression in cultured cells. Methods Enzymol. 393, 543-557 
203 Huang, T. S., Grodeland, G., Sleire, L., Wang, M. Y., Kvalheim, G. and Laerum, O. D. (2009) Induction of circadian rhythm in cultured human mesenchymal stem cells by serum shock and cAMP analogs in vitro. Chronobiol Int. 26, 242-257

204 Wu, X., Zvonic, S., Floyd, Z. E., Kilroy, G., Goh, B. C., Hernandez, T. L., Eckel, R. H., Mynatt, R. L. and Gimble, J. M. (2007) Induction of circadian gene expression in human subcutaneous adipose-derived stem cells. Obesity (Silver Spring). 15, 2560-2570

205 Fan, Y., Hida, A., Anderson, D. A., Izumo, M. and Johnson, C. H. (2007) Cycling of CRYPTOCHROME proteins is not necessary for circadian-clock function in mammalian fibroblasts. Curr Biol. 17, 1091-1100

206 Nonaka, H., Emoto, N., Ikeda, K., Fukuya, H., Rohman, M. S., Raharjo, S. B., Yagita, K., Okamura, H. and Yokoyama, M. (2001) Angiotensin II induces circadian gene expression of clock genes in cultured vascular smooth muscle cells. Circulation. 104, 1746-1748

207 Garner, W. W. and Allard, H. A. (1920) Effect of the relative length of day and night and other factors of the environment on growth and reproduction in plants. J Agric Res 18, 553-606

208 Wilkins, M. B. (1960) Effects of light and darkness on the rhythm of output of carbon dioxide of excised Bryophyllum leaves. Nature. 187, 523-525

209 Wilkins, M. B. (1962) An endogenous rhythm in the rate of carbon dioxide output of Bryophyllum. IV. Effect of intensity of illumination on entrainment of the rhythm by cycles of light \& darkness. Plant Physiol. 37, 735-741

210 Gardner, M. J., Hubbard, K. E., Hotta, C. T., Dodd, A. N. and Webb, A. A. (2006) How plants tell the time. Biochem J. 397, 15-24

211 Yakir, E., Hilman, D., Harir, Y. and Green, R. M. (2007) Regulation of output from the plant circadian clock. Febs J. 274, 335-345

212 Mas, P. (2008) Circadian clock function in Arabidopsis thaliana: time beyond transcription. Trends Cell Biol. 18, 273-281

213 Kloppstech, K. (1985) Diurnal and circadian rhythmicity in the expression of lightinduced plant nuclear messenger RNAs. Planta. 165, 502-506

214 Giuliano, G., Hoffman, N. E., Ko, K., Scolnik, P. A. and Cashmore, A. R. (1988) A lightentrained circadian clock controls transcription of several plant genes. Embo J. 7, 36353642

215 Meyer, H., Thienel, U. and Piechulla, B. (1989) Molecular characterization of the diurnal/circadian expression of the chlorophyll a/b-binding proteins in leaves of tomato and other dicotyledonous and monocotyledonous plant species. Planta. 180, 5-15

216 Wang, Z. Y., Kenigsbuch, D., Sun, L., Harel, E., Ong, M. S. and Tobin, E. M. (1997) A Myb-related transcription factor is involved in the phytochrome regulation of an Arabidopsis Lhcb gene. Plant Cell. 9, 491-507

217 Millar, A. J., Carre, I. A., Strayer, C. A., Chua, N. H. and Kay, S. A. (1995) Circadian clock mutants in Arabidopsis identified by luciferase imaging. Science. 267, 1161-1163

218 Strayer, C., Oyama, T., Schultz, T. F., Raman, R., Somers, D. E., Mas, P., Panda, S., Kreps, J. A. and Kay, S. A. (2000) Cloning of the Arabidopsis clock gene TOC1, an autoregulatory response regulator homolog. Science. 289, 768-771

219 Makino, S., Kiba, T., Imamura, A., Hanaki, N., Nakamura, A., Suzuki, T., Taniguchi, M., Ueguchi, C., Sugiyama, T. and Mizuno, T. (2000) Genes encoding pseudo-response regulators: insight into His-to-Asp phosphorelay and circadian rhythm in Arabidopsis thaliana. Plant Cell Physiol. 41, 791-803

220 McClung, C. R. (2006) Plant circadian rhythms. Plant Cell. 18, 792-803 
221 Fujiwara, S., Wang, L., Han, L., Suh, S. S., Salome, P. A., McClung, C. R. and Somers, D. E. (2008) Post-translational regulation of the Arabidopsis circadian clock through selective proteolysis and phosphorylation of pseudo-response regulator proteins. J Biol Chem. 283, 23073-23083

222 Wang, Z. Y. and Tobin, E. M. (1998) Constitutive expression of the CIRCADIAN CLOCK ASSOCIATED 1 (CCA1) gene disrupts circadian rhythms and suppresses its own expression. Cell. 93, 1207-1217

223 Hayama, R. and Coupland, G. (2003) Shedding light on the circadian clock and the photoperiodic control of flowering. Curr Opin Plant Biol. 6, 13-19

224 Webb, A. A. R. (2003) The physiology of circadian rhythms in plants. New Phytol 160, 281-303

225 Barak, S., Tobin, E. M., Andronis, C., Sugano, S. and Green, R. M. (2000) All in good time: the Arabidopsis circadian clock. Trends Plant Sci. 5, 517-522

226 Harmer, S. L. (2009) The circadian system in higher plants. Annu Rev Plant Biol. 60, 357-377

227 Lin, C. (2002) Blue light receptors and signal transduction. Plant Cell. 14 Suppl, S207225

228 Devlin, P. F. and Kay, S. A. (2000) Cryptochromes are required for phytochrome signaling to the circadian clock but not for rhythmicity. Plant Cell. 12, 2499-2510

229 Perales, M. and Mas, P. (2007) A functional link between rhythmic changes in chromatin structure and the Arabidopsis biological clock. Plant Cell. 19, 2111-2123

230 Gould, P. D., Locke, J. C., Larue, C., Southern, M. M., Davis, S. J., Hanano, S., Moyle, R., Milich, R., Putterill, J., Millar, A. J. and Hall, A. (2006) The molecular basis of temperature compensation in the Arabidopsis circadian clock. Plant Cell. 18, 1177-1187

231 Locke, J. C., Kozma-Bognar, L., Gould, P. D., Feher, B., Kevei, E., Nagy, F., Turner, M. S., Hall, A. and Millar, A. J. (2006) Experimental validation of a predicted feedback loop in the multi-oscillator clock of Arabidopsis thaliana. Mol Syst Biol. 2, 59

232 Locke, J. C., Southern, M. M., Kozma-Bognar, L., Hibberd, V., Brown, P. E., Turner, M. S. and Millar, A. J. (2005) Extension of a genetic network model by iterative experimentation and mathematical analysis. Mol Syst Biol. 1, 20050013

233 Gooch, V. D., Freeman, L. and Lakin-Thomas, P. L. (2004) Time-lapse analysis of the circadian rhythms of conidiation and growth rate in Neurospora. J Biol Rhythms. 19, 493503 


\section{Figure Legends}

\section{Figure 1.}

Schematic representation of a molecular mechanism for circadian oscillations with negative and positive feedback loops. Positive components/transcription factors interact with the promoter regions of clock genes leading to their expression and forming corresponding mRNAs and proteins. Some clock gene activation mechanisms may involve positive feedback loops. As supported by model calculations [40, 42, 43], the crucial element for getting oscillations is presence of one (or several) negative feedback loop(s), in which a clock protein inhibits its own transcription. Environmental influences affect the clock mechanism through a series of receptors which alter properties of clock proteins and their transcription factors through kinases and phosphatases, where some of phospohorylation and dephosphorylation pathways appear to be mechanistically conserved [69].

\section{Figure 2.}

Growth tubes monitoring the free-running circadian rhythm in Neurospora. The sterile tubes contain growth medium (agar) and are sealed on each side with cotton plugs allowing air exchange. Inoculation with mycelium or conidia occur at one side of the tube. Under free-running conditions, generally in darkness or under a red safety light, the mycelium then grows along the tube with approximately constant speed [233]. Approximately every $22 \mathrm{~h}$ conidia are formed seen as the patches on the tube reflecting the output of the circadian clock. The period of the freerunning rhythm can be determined by measuring the distance between the conidial patches and dividing this distance by the growth speed.

\section{Figure 3.}

Scheme of the circadian core network in Neurospora crassa. Several negative feedback loops have been identified. The FRQ protein plays a central role. Its highly regulated stability defines period length and temperature compensation of the conidiation rhythm [63, 64]. Additional feedback loops are also indicated. They seem to serve special purposes, for example when nitrate ion is the only source for nitrogen, or, as in the case of VIVID (VVD), playing a role in the phasing of the rhythm.

\section{Figure 4.}

Model of the circadian core network in mammals. The heterodimer CLOCK/BMAL activates genes containing an E-box. CRY, the PER proteins and REV-ERB $\alpha$ are negative elements, while the ROR proteins together with CLOCK and BMAL1 define positive elements. For a more detailed discussion, see main text.

\section{Figure 5.}

Feedback loops of the plant circadian network. Three loops are presently considered, the dawnphased CCA1/LHY containing loop, which negatively regulates TOC1, a morning-phased loop containing the PRR proteins inhibiting the formation of CCA1/LHY, and an evening-phased loop, probably through GIGANTEA (GI) activating TOC1. 


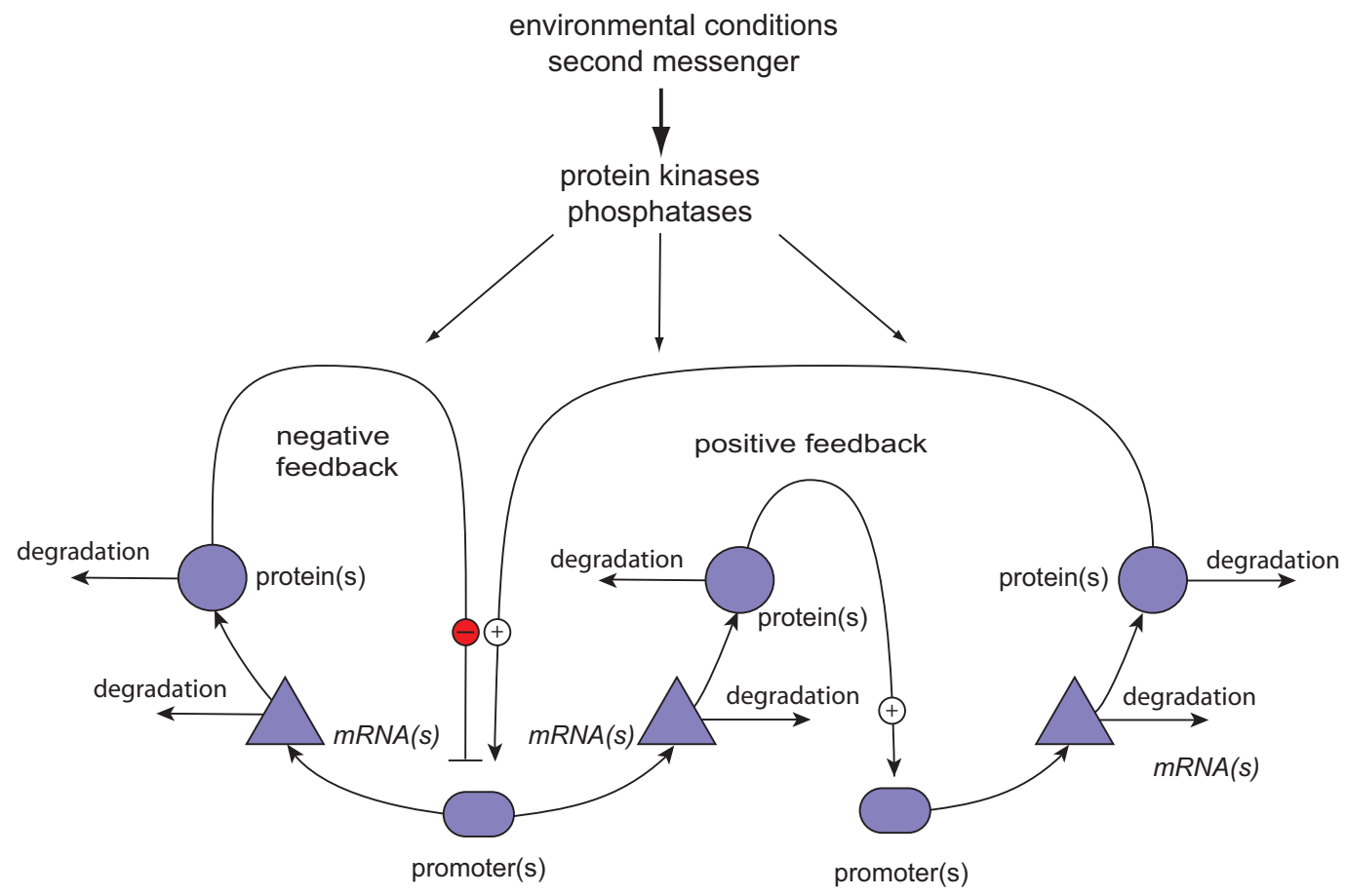

Fig. 1 


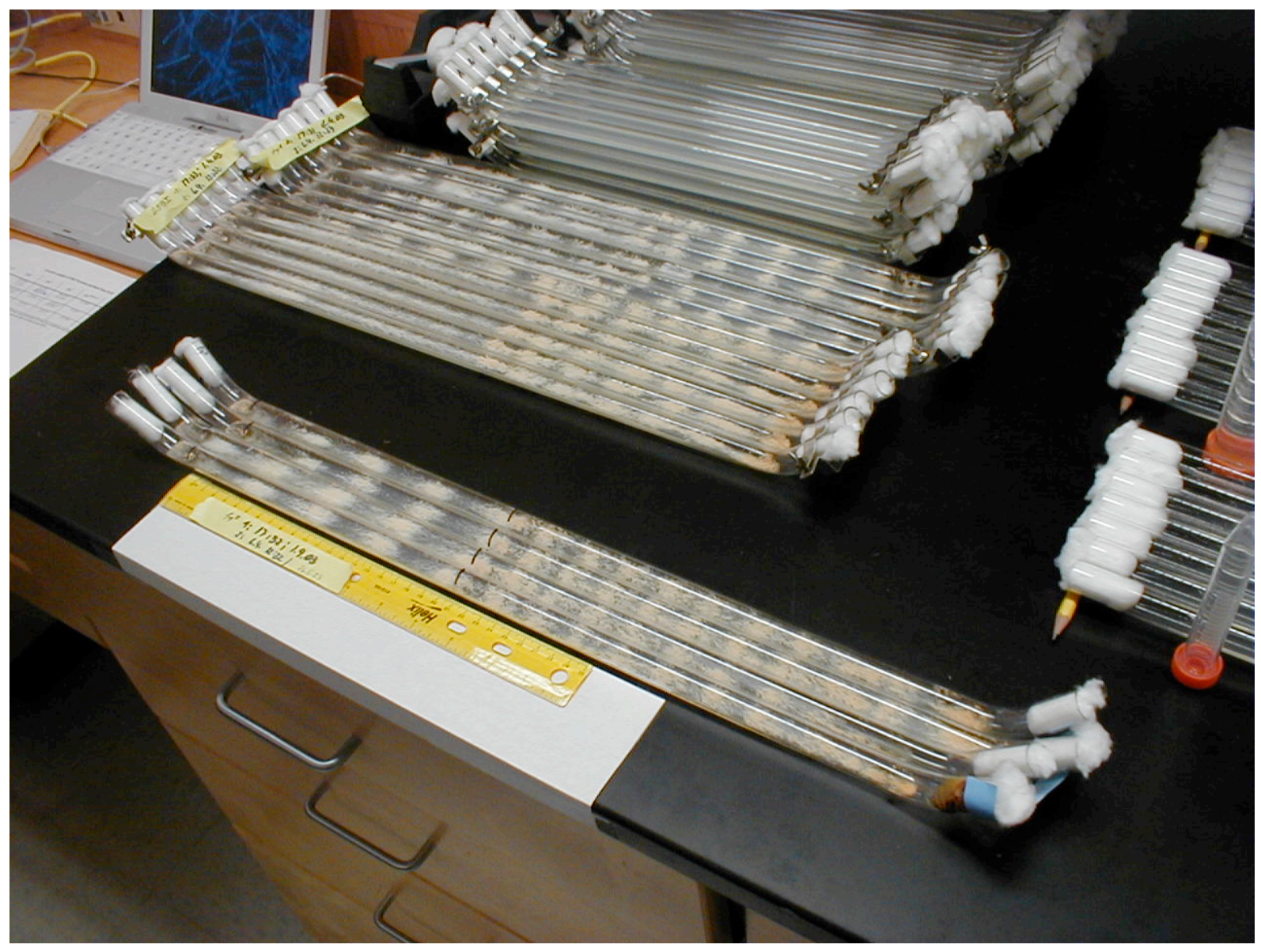

Fig. 2 


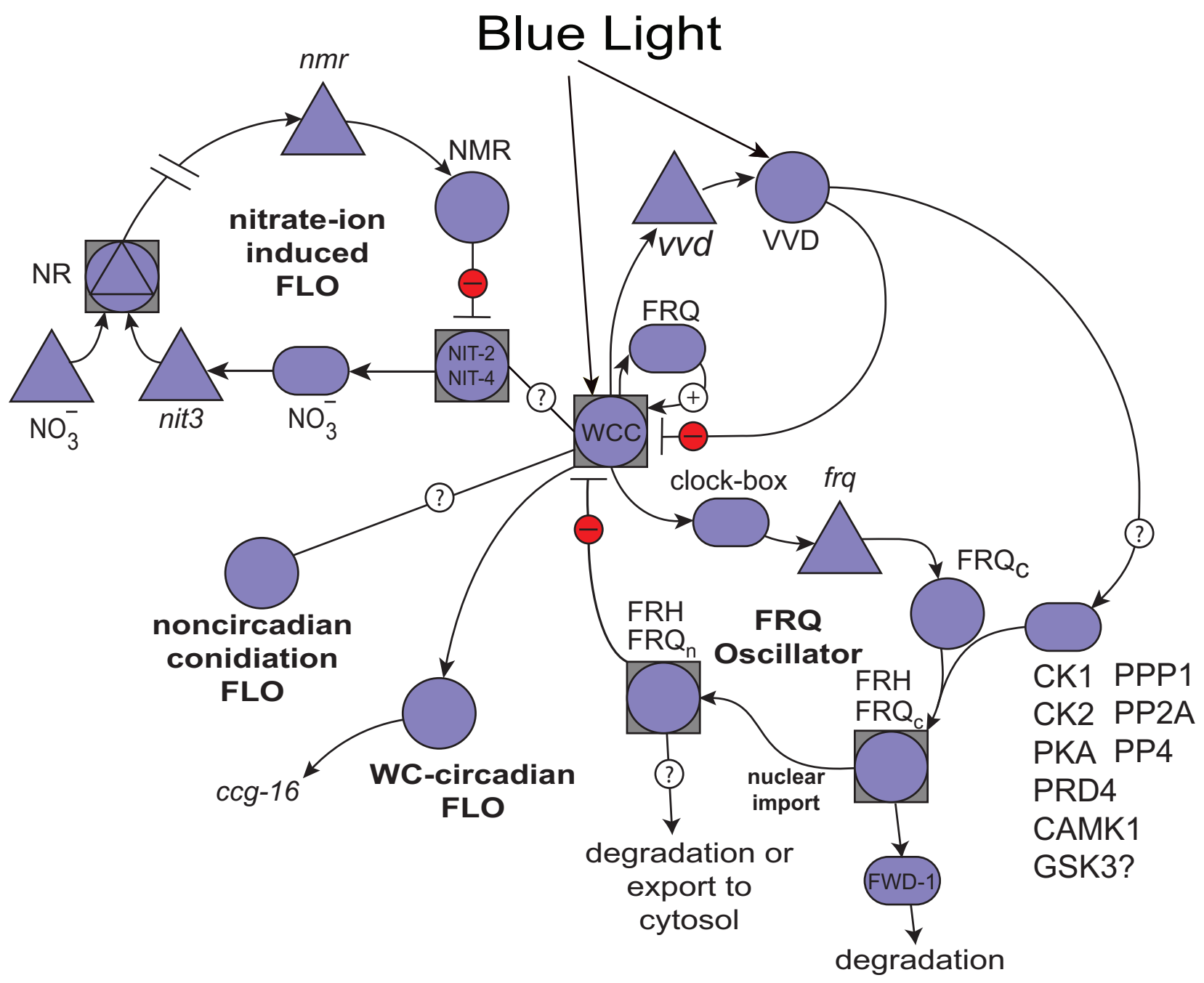

Fig. 3 


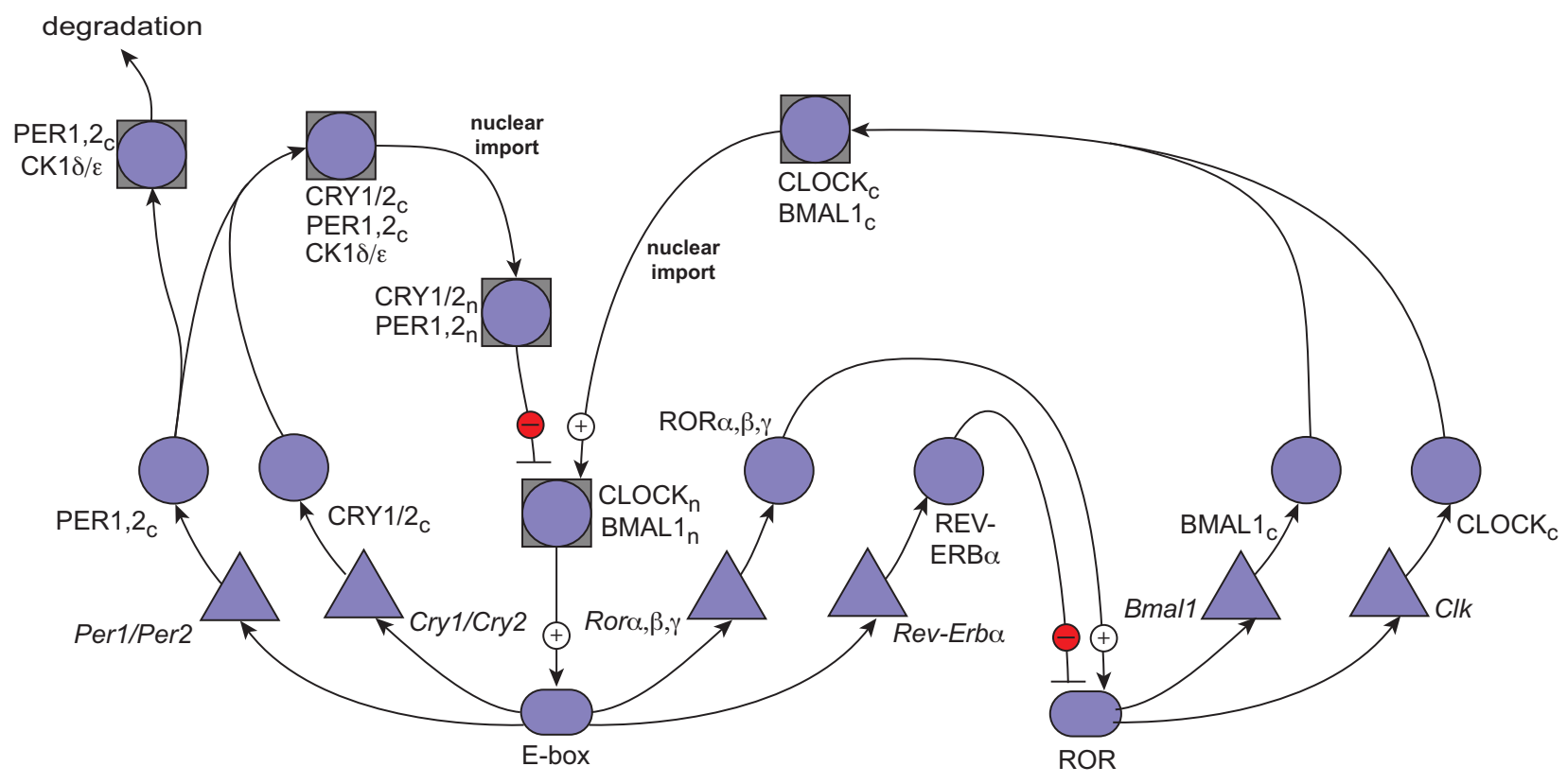

Fig. 4 


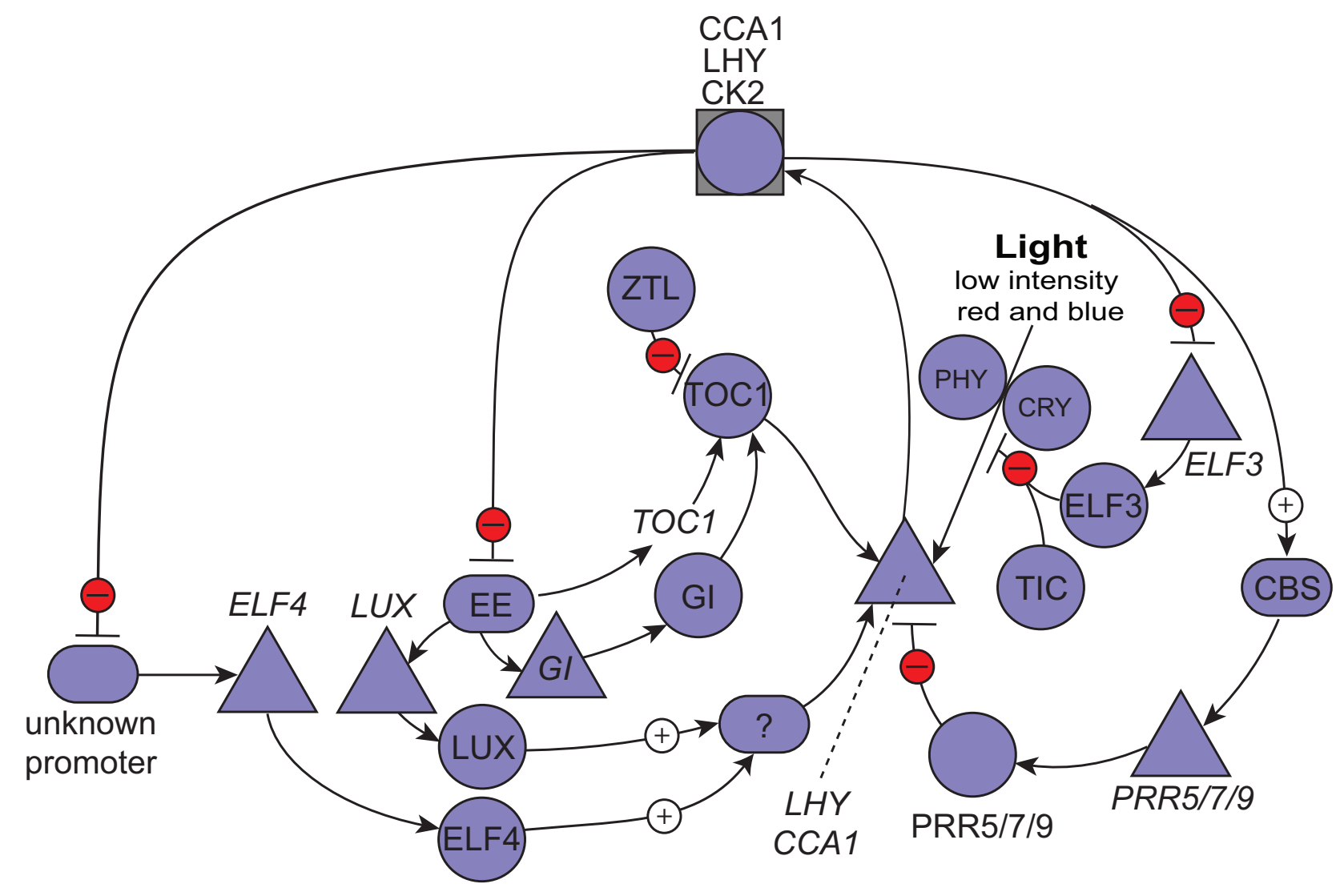

Fig. 5 